\title{
Data report: permeability, grain size, biogenic silica, and clay minerals of Expedition 341 sediments from Sites U1417 and U1418'
}

\author{
Elizabeth J. Screaton, ${ }^{2}$ Tania Villaseñor ${ }^{2}$ Stephanie R. James, ${ }^{2}$ Lanie N. Meridth, ${ }^{2}$ John M. Jaeger, ${ }^{2}$ and \\ William F. Kenney ${ }^{3}$
}

\section{Chapter contents}

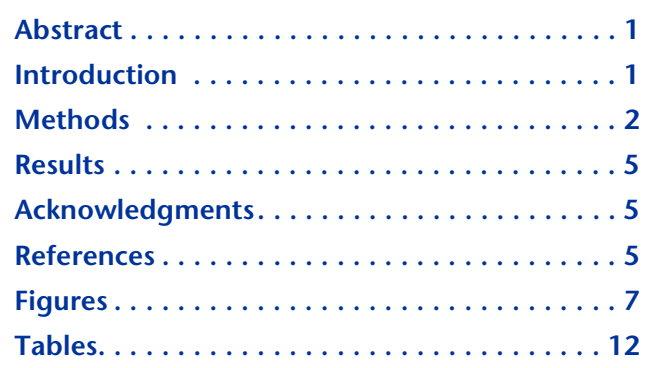

${ }^{1}$ Screaton, E.J., Villaseñor, T., James, S.R., Meridth, L.N., Jaeger, J.M., and Kenney, W.F., 2017. Data report: permeability, grain size, biogenic silica, and clay minerals of Expedition 341 sediments from Sites U1417 and U1418. In Jaeger, J.M., Gulick, S.P.S., LeVay, L.J., and the Expedition 341 Scientists, Proceedings of the Integrated Ocean Drilling Program, 341: College Station, TX (Integrated Ocean Drilling Program). doi:10.2204/iodp.proc.341.202.2017 ${ }^{2}$ Department of Geological Sciences, University of Florida, Gainesville FL 32611, USA.

Correspondence author. screaton@ufl.edu ${ }^{3}$ Land Use and Environmental Change Institute, University of Florida, Gainesville FL 32611, USA.

\section{Abstract}

Eleven whole-round core samples from Integrated Ocean Drilling Program Expedition 341 Sites U1417 and U1418 were tested for vertical permeability. Subsamples of each core were taken and analyzed for grain size, biogenic silica content, and clay mineralogy. Measured vertical permeability varied from $1.8 \times 10^{-18}$ to $1.5 \times 10^{-}$ ${ }^{16} \mathrm{~m}^{2}$. With the exception of one sample from Site U1417, samples were dominated by clay-size $(<4 \mu \mathrm{m})$ fractions with lesser silt-size $(4-63 \mu \mathrm{m})$ and sand-size $(>63 \mu \mathrm{m})$ fractions. Biogenic silica $\left(\mathrm{SiO}_{2}\right)$ content ranged from 2 to $15 \mathrm{wt} \%$ at Site U1417 and was consistently $\sim 2 \mathrm{wt} \%$ in samples from Site U1418. Clay mineral abundance exceeded that of quartz, feldspar, and calcite in all samples. Smectite content ranged from 3 to $38 \mathrm{wt} \%$ in Site U1417 samples and from 0 to $3 \mathrm{wt} \%$ in Site U1418 samples.

\section{Introduction}

Operations during Integrated Ocean Drilling Program Expedition 341 recovered cores from off the coast of the Gulf of Alaska (Fig. F1; see the "Expedition 341 summary" chapter [Jaeger et al., 2014]). In this study, we used flow-through permeability tests to measure the permeability of five whole-round core samples from Site U1417 and six whole-round core samples from Site U1418. Subsamples from the core used for permeability testing were divided for grain size, biogenic silica, and clay mineral analyses. The uppermost sample at Site U1417 consists of distal Surveyor Fan sediments, and the other four samples from this site consist of pre-Surveyor Fan sediments. The samples from Site U1418 represent proximal Surveyor Fan sediments.

The objective of the testing was to help characterize the sediments that are being carried toward the Aleutian Trench on the incoming Pacific plate (Fig. F1). The permeability of sediments entering subduction zones can greatly affect fluid pressures during shallow subduction, and this work provides some of the first permeability results from the incoming plate in this region. Analysis of amorphous silica and clay mineral content provides information on hydrous sedimentary minerals that can dehydrate during subduction or accretion and increase fluid pressures (Screaton, 2010). 


\section{Methods}

\section{Permeability tests}

The methods for permeability testing are similar to those of previous studies (e.g., James and Screaton, 2015) and were based on American Society for Testing and Materials (ASTM) designation D5084-90 (ASTM International, 1990). Permeability tests used Trautwein Soil Testing Equipment Company's DigiFlow K, which consisted of a cell to contain the sample and provide isostatic effective stress and three pumps (Fig. F2). Deionized water was used as the fluid in the pumps, and a solution of $33 \mathrm{~g} \mathrm{NaCl}$ per liter of water permeated the sample. Pressure was transmitted from the deionized water to the permeant across a rubber membrane in an interface chamber (Fig. F2).

The retrieved core samples from Expedition 341 were stored in plastic core liners and sealed bags to prevent moisture loss and refrigerated at $4^{\circ} \mathrm{C}$ until immediately before sample preparation. All tests were conducted with flow in the vertical direction (along the axis of the core) using the whole-round core. To provide freshly exposed surfaces, cores were trimmed on both ends using a cutting tool or wire saw, depending on core properties. Visual inspection was used to select portions of the core that were relatively uniform in composition and not disturbed or fractured. After trimming the ends of the sample, diameters of the trimmed whole-round cores ranged from 5.2 to $6.3 \mathrm{~cm}$, and sample heights ranged from 6.2 to $9.0 \mathrm{~cm}$. The sample was then placed in a rubber membrane and fitted with saturated porous disks and end caps. The membrane-encased sample was placed in the cell, which was then filled with deionized water. Fluid exchange occurs only through the flows lines connecting the end caps to the top and bottom pumps. A small confining pressure of $\sim 0.03$ $\mathrm{MPa}(5 \mathrm{psi})$ was applied to the water in the cell, and flow lines were flushed to remove any trapped air bubbles. After flushing the flow lines, the sample was backpressured to either $\sim 0.28 \mathrm{MPa}$ (40 psi) or $\sim 0.41$ $\mathrm{MPa}$ (60 psi) by concurrently ramping the cell pressure and the sample pressure to maintain a constant effective stress of $0.03 \mathrm{MPa}$ (5 psi). Backpressure was maintained at least $24 \mathrm{~h}$. Subsequently, the cell fluid pressure was increased while the sample backpressure was maintained, thus increasing the effective stress on the sample. This effective stress both consolidated the sample and pushed the flexible membrane against the sample to prevent flow bypassing the sample.

Because the whole-round samples were sealed immediately after cutting the core liner, the samples were expected to be near saturation prior to testing. Back- pressuring at $0.28 \mathrm{MPa}$ (40 psi) for $\sim 24 \mathrm{~h}$ is sufficient to ensure full saturation under these conditions (ASTM International, 1990). A B-test on each sample was used to check saturation. In a B-test, the cell confining pressure was instantaneously increased by $10 \mathrm{psi}$ and the sample response was measured. The ratio of sample pressure change to cell pressure change is the Skempton B-coefficient, which is typically near 1 for soft to medium clays (Wang, 2000), and a B-test result 0.95 is typically used to indicate saturation for soft to medium clays. This criterion is not applicable for more consolidated materials because compiled B-coefficients for mudstone, sandstone, and limestone are $0.95,0.50$ to 0.88 , and 0.25 , respectively (Wang, 2000). Samples below 0.95 were given additional time for saturation or backpressure was increased. Saturation was assumed if the B-value did not change with increased time.

For each sample location, in situ effective stress was estimated using the shipboard bulk density measurements of the overlying sediments. Effective stress increments between depths of shipboard measurements were calculated assuming hydrostatic fluid pressures and summed. The estimated in situ effective stress is generally much greater than what was reached in the laboratory testing. Although these permeability values should not be assumed to reflect in situ conditions, they can be used to construct permeability-porosity relationships for use in fluid-flow modeling (e.g., Daigle and Screaton, 2015).

For every sample, flow tests were performed at two different effective stress steps. Once the target effective stress was achieved for each step, cell pressure and backpressure were maintained. The sample was allowed to equilibrate for at least $12 \mathrm{~h}$ and generally for $24 \mathrm{~h}$. Throughout testing, inflows and outflows to the cell fluid were monitored to assess changes in sample volume, and sample data were recorded every minute. Because fluid pressure in the closed hydraulic system was affected by temperature changes, testing was conducted within a closed cabinet to keep the internal temperature uniform. Testing temperatures were $28^{\circ} \pm 1^{\circ} \mathrm{C}$. Two or more flow tests were performed at each effective stress level, with flow direction varied between tests. Flow tests were run at specific pressures of the top and bottom pump while recording flow rates into and out of the sample.

The pressure difference $(\Delta P)$ from the top and bottom pumps were converted to hydraulic head difference $(\Delta h)$ :

$$
\Delta h=\Delta P / \rho_{\mathrm{w}} \mathrm{g}
$$

where 
$\rho_{\mathrm{w}}=$ fluid density $\left(1021 \mathrm{~kg} / \mathrm{m}^{3}\right)$, and

$\mathrm{g}=$ acceleration due to gravity $\left(9.81 \mathrm{~m} / \mathrm{s}^{2}\right)$.

Darcy's law was used to calculate the hydraulic conductivity:

$$
Q=-K A(\Delta h / \Delta l)
$$

where

$Q=$ measured flow rate (in cubic meters per second),

$K=$ hydraulic conductivity (in meters per second),

$A=$ the cross-sectional area of the sample (in square meters),

$\Delta h=$ the difference in head across the sample (in meters), and

$\Delta l=$ the length of the sample (in meters).

The hydraulic conductivity values $(k)$ were then converted to permeability (in square meters) using the following equation:

$$
k=(K \mu) /(\rho g),
$$

where

$$
\begin{aligned}
& \rho=\text { fluid density }\left(1021 \mathrm{~kg} / \mathrm{m}^{3}\right), \\
& \mathrm{g}=\text { acceleration due to gravity }\left(9.81 \mathrm{~m} / \mathrm{s}^{2}\right) \text {, and } \\
& \mu=\text { viscosity }(0.000893 \mathrm{~Pa} \cdot \mathrm{s}) .
\end{aligned}
$$

For the laboratory temperature (averaging $28^{\circ} \mathrm{C}$ ) and fluid salinity $(33 \mathrm{~g} / \mathrm{L})$, a fluid density of $1021 \mathrm{~kg} / \mathrm{m}^{3}$ and viscosity of $0.000893 \mathrm{~Pa} \cdot \mathrm{s}$ were calculated based on relationships compiled by Sharqawy et al. (2010). Assuming reasonable water compressibility, density change caused by the applied pressure was minor $(<0.1 \%)$. A $1 \mathrm{~h}$ interval of stable flow rates was averaged for the permeability calculations, and the standard deviation of the permeability during that interval was calculated to assess uncertainty. The fluctuations in the calculated permeability are likely caused by slight temperature variations. The resulting volume changes would cause temporary changes in measured flow rates. The time interval was selected based on where inflow best matched outflow, indicating steady-state conditions, and where the standard deviation was minimized.

The corresponding porosity for each effective stress was calculated using the change in volume of fluid (milliliters) contained in the cell during each consolidation step. The volume change during consolidation was assumed to be solely a result of changes in sample porosity. Influences of material and apparatus stiffness were assumed to be negligible. Total sample volume $\left(V_{\mathrm{T}(0)}\right)$ was calculated using $\pi r^{2} h$, where $r$ is the radius of the core sample and $h$ is the height of the sample. Initial porosities $\left(n_{0}\right)$ for vol- ume calculations were obtained from the shipboard moisture and density results (see the "Expedition 341 summary" chapter [Jaeger et al., 2014]). The two nearest shipboard measurements were averaged for each sample. We assumed that the porosity of the sample at the end of backpressure is similar to the initial porosity $\left(n_{0}\right)$ of the sample because of the small change in effective stress (0.03 $\mathrm{MPa})$.

Using the initial porosity $\left(n_{0}\right)$, the volume of voids before the testing $\left(V_{\mathrm{v}(0)}\right)$ was calculated:

$$
V_{\mathrm{v}(0)}=n_{0} V_{\mathrm{T}(0)} .
$$

Volume of solids $\left(V_{s}\right)$ was calculated using

$$
V_{\mathrm{s}}=V_{\mathrm{T}(0)}-V_{\mathrm{v}(0)}
$$

The change in volume of water in the cell $\left(\Delta V_{\mathrm{T}(1)}\right)$ was calculated using the difference of cell volumes between two consecutive steps (e.g., cell volume at backpressure and cell volume at first consolidation). The new total volume of the sample $\left(V_{\mathrm{T}(1)}\right)$ after pore spaces were reduced during the consolidation process was determined by subtracting the change in cell volume at the end of the consolidation step $\left(\Delta V_{\mathrm{T}(1)}\right)$ from the total sample volume $\left(V_{\mathrm{T}(0)}\right)$ :

$$
V_{\mathrm{T}(1)}=V_{\mathrm{T}(0)}-\Delta V_{\mathrm{T}(1)} .
$$

Using the calculated new total volume of the sample $\left(V_{\mathrm{T}(1)}\right)$, the new porosity at the end of the consolidation $\left(n_{1}\right)$ was calculated as

$$
n_{1}=\left(V_{\mathrm{T}(1)}-V_{\mathrm{S}}\right) / V_{\mathrm{T}(1)} .
$$

\section{Grain size analyses}

Subsamples were extracted in $1.5 \mathrm{~cm}$ thick intervals from the permeability sample after completion of the permeability tests. Because the cores used for permeability testing were relatively consistent in composition, the subsamples were assumed to be representative. The subsamples were homogenized and used for grain size, biogenic silica, and clay mineral analyses.

For grain size analyses, the samples were disaggregated in a solution of sodium hexametaphosphate to inhibit clay flocculation. Subsamples were also immersed in an ultrasonic bath for a minimum of $2 \mathrm{~h}$ to assist disaggregation. A small aliquot of the homogenized sample was dried to determine water content, which was then used to establish the equivalent dry mass used in the particle size analysis. Once disaggregated, a subsample was wet sieved at $63 \mu \mathrm{m}$ to determine the sand-size fraction. A sepa- 
rate subsample was wet sieved at $53 \mu \mathrm{m}$, and material smaller than $53 \mu \mathrm{m}$ was analyzed on a $5100 \mathrm{Mi}-$ crometrics SediGraph (Coakley and Syvitski, 1991). The SediGraph emits X-rays that record the settling rates of particles suspended in a sodium hexametaphosphate solution. The principle of Stoke's law was used to calculate grain sizes. The SediGraph data were combined with the wet-sieved results to normalize the mud and sand fraction to their relative masses to determine the proportion of sand-, silt-, and clay-size particles. Clay-size particles were defined as smaller than $4 \mu \mathrm{m}$ based on the Wentworth grain-size classification.

\section{Silica analyses}

To determine the amount of biogenic silica in each sample, an alkaline leaching method was used, as outlined by DeMaster (1981) and Spinelli and Underwood (2004). As noted by Spinelli and Hutton (2013), this method can include other amorphous silica in addition to biogenic opal. The subsamples were digested in $40 \mathrm{~mL}$ of $0.0316 \mathrm{M} \mathrm{NaOH}$ at $85^{\circ} \mathrm{C}$. Biogenic opal and other amorphous silica digests more rapidly in alkaline solution than clay minerals, resulting in a rapid increase in silica concentration in the alkaline solution (Spinelli and Underwood, 2004). However, this signal can be overprinted by dissolution of silicate clay minerals. Thus, continuous dissolution of the samples was monitored over a total of $5 \mathrm{~h}$. DeMaster (1981) found that alumino-silicates from clay dissolution release silica linearly over time. Most of the silica is dissolved within $2 \mathrm{~h}$ of digestion (Grasshoff et al., 1983). The concentration of silica (milligrams of $\mathrm{SiO}_{2}$ per gram) in the leachate after $0,1,2,3,4$, and $5 \mathrm{~h}$ was determined by spectrophotometry. The intercept of the regression through the 3-5 h measurements was used to calculate the concentration of amorphous silica (Saccone et al., 2006).

\section{Clay mineral analyses}

Quantitative X-ray clay mineralogy followed methods described in Underwood et al. (2003). The method uses normalization factors determined after measuring the X-ray diffraction peak area produced by standard mineral mixtures with known weight percentages of each component. The total content of clay minerals was determined using the X-ray diffractogram of the bulk sediment samples, whereas clay mineralogy of the $<2 \mu \mathrm{m}$ fraction was studied using preferentially oriented mounts (Moore and Reynolds, 1997).

Standard mineral mixtures (Table T1) and splits of freeze-dried bulk sediment samples were gently disaggregated using a mortar and pestle, mixed with distilled water, and ground in a McCrone micronizing mill for 5 min to homogenize the samples. Each sample was oven-dried at $40^{\circ} \mathrm{C}$ overnight and sieved at $125 \mu \mathrm{m}$. Standard mixtures and bulk samples were side-loaded in aluminum sample holders to ensure random orientation and analyzed in a Rigaku Ultima $\mathrm{X}$-ray diffraction system at $40 \mathrm{kV}, 35 \mathrm{~mA}$, incidence angle from $3^{\circ}$ to $35^{\circ} 2 \theta, 0.01^{\circ} 2 \theta$ step size, and scan speed of $1^{\circ} 2 \theta / \mathrm{min}$.

A portion of each bulk sediment sample (3-4 g) was mixed with $0.05 \%$ sodium hexametaphosphate and placed in an ultrasonic bath for $60 \mathrm{~min}$ to facilitate particle disaggregation. After $>24 \mathrm{~h}$, samples were wet-sieved at $63 \mu \mathrm{m}$ to remove the sand fraction. The $<63 \mu \mathrm{m}$ fraction of each sample was centrifuged for $36 \mathrm{~s}$ to extract the fraction finer than $2 \mu \mathrm{m}$. This procedure was repeated 4-5 times per sample to ensure extraction of all $<2 \mu \mathrm{m}$ particles from the sediment. Oriented samples were mounted in glass slides following Moore and Reynolds (1997). Each sample was analyzed in the X-ray diffractometer with the incidence angle varying from $3^{\circ}$ to $23^{\circ} 2 \theta$ at a $0.01^{\circ} 2 \theta$ step with a scan speed of $1 \mathrm{~s} / \mathrm{step}$. To evaluate the presence of smectite in the clay fraction of the sediment, the sample slides were put in a sealed desiccator with an ethylene glycol bath at $60^{\circ}-65^{\circ} \mathrm{C}$ for $\sim 18$ $\mathrm{h}$, after which they were analyzed in the X-ray diffractometer under the previous conditions.

The diffractograms of the mineral standard mixtures, bulk samples, and clay mineral slides were processed in MacDiff (version 4.2.6; http://www.ccp14.ac.uk/ ccp/web-mirrors/krumm/macsoftware/macdiff/ MacDiff.html). Normalization factors used to semiquantify the mineralogy were calculated using the diffractograms of the standard mixtures and using the normalization factor technique proposed by Fisher and Underwood (1995). The area of the basal peaks used to estimate the normalization factors were calculated using the Pearson VII pattern fit:

- Composite clay mineral at $\sim 19.8^{\circ} 2 \theta(\mathrm{d}=4.49$ $\AA)$;

- Quartz (101) at $26.65^{\circ} 2 \theta(\mathrm{d}=3.34 \AA)$;

- Double peak for plagioclase at $27.77^{\circ}-28.02^{\circ} 2 \theta$ $(\mathrm{d}=3.21-3.18 \AA)$; and

- Calcite (104) at $29.42^{\circ} 2 \theta(d=3.04 \AA)$.

These factors were used to semiquantify total clays, quartz, plagioclase, and calcite in the bulk sediment samples (Fig. F3).

For the $<2 \mu \mathrm{m}$ fraction, quantification of smectite (15-17 $⿱$ $)$, illite $(10 \AA)$, and chlorite/kaolinite (7 $⿱$ ) was done following Biscaye (1965), using the diffractograms of the glycolated clay mineral slides (Spinelli and Underwood, 2004) (Fig. F3). This method considers the area under the basal peaks corrected by 
weighing factors: $1 \times$ for smectite, $4 \times$ for illite, and $2 \times$ for chlorite/kaolinite. Semiquantification results were obtained after normalization of the peak areas ( $\%$ smectite $+\%$ illite $+\%$ chlorite $/$ kaolinite $=100 \%)$. Based on these results, the proportion of each clay mineral in the bulk sample was calculated using the total clay mineral content (weight percent), and the total biogenic opal (weight percent) measured in the bulk sample following Spinelli and Underwood (2004). Underwood et al. (2003) reports that the Biscaye peak area method underestimates the amount of smectite by $7-17 \mathrm{wt} \%$ and overestimates illite and chlorite by as much as 16 and $8 \mathrm{wt} \%$, respectively. However, we used the Biscaye (1965) method because it is a readily available method to determine relative variations in clay mineralogy in the absence of clay mineral standards (e.g., Underwood et al., 2003).

\section{Results}

Table T2 summarizes the effective stress and estimated porosity and permeability at each consolidation step as well as the grain size distribution for each sample. Table T3 summarizes the biogenic silica results. Tables T4 and T5 present the area of the basal peaks used to estimate the normalization factors and the calculated normalization factors, respectively. With the exception of the sample from Section 341U1417D-43X-3, clay mineral abundance exceeded that of quartz, feldspar, and calcite in all samples (Table T6). Smectite content ranged from 3 to $38 \mathrm{wt} \%$ in Site U1417 samples and from 0 to $3 \mathrm{wt} \%$ in Site U1418 samples (Table T7).

Results are shown on Figures F4 and F5 for Sites U1417 and U1418, respectively. At Site U1417, permeability and silica content show similar variations with depth, with the highest values at 474.8 meters below seafloor. Porosity also shows higher values in this depth range, although results are greatly affected by scatter. Additional samples would be needed to distinguish interrelationships between these properties. Relative to Site U1417, Site U1418 shows much less variation in porosity, permeability, and biogenic silica content (Fig. F5).

Measured vertical permeability varied from $1.8 \times$ $10^{-18}$ to $1.5 \times 10^{-16} \mathrm{~m}^{2}$. Except for the sample from Section 341-U1417D-43X-3, which contained predominantly silt-size particles, all samples were dominated by clay-size particles. Sand-size particles ranged between 0 and $27 \mathrm{wt} \%$.

Surveyor Fan sediments are represented by the uppermost sample of Site U1417 and the samples of Site U1418, showing low biogenic silica content $(\sim 2$ $w t \%)$ and low smectite content ( $\leq 3 \mathrm{wt} \%)$. The preSurveyor Fan sediments (i.e., the lower four samples from Site U1417) have $2-15 \mathrm{wt} \%$ biogenic silica and 9-38 wt\% smectite in the bulk sample.

\section{Acknowledgments}

This research used samples and data provided by the Integrated Ocean Drilling Program (IODP). Funding for this research was provided by a Consortium for Ocean Leadership U.S. Scientist Support Program postcruise grant to J. Jaeger and National Science Foundation Grant EAR-0819769. We thank Andy Fisher for sharing his X-ray diffraction pattern analysis code, Mike Underwood for insight on clay analyses, and Julia Reece for helpful recommendations.

\section{References}

ASTM International, 1990. Standard test method for measurement of hydraulic conductivity of saturated porous materials using a flexible wall permeameter (Standard D5084-70). In Annual Book of ASTM Standards: Philadelphia (American Society for Testing and Materials), 6370.

Biscaye, P.E., 1965. Mineralogy and sedimentation of recent deep-sea clay in the Atlantic Ocean and adjacent seas and oceans. Geological Society of America Bulletin, 76(7):803-831. http://dx.doi.org/10.1130/00167606(1965)76[803:MASORD]2.0.CO;2

Coakley, J.P., and Syvitski, J.P.M., 1991. SediGraph technique. In Syvitski, J.P.M. (Ed.), Principles, Methods, and Application of Particle Size Analysis: Cambridge, UK (Cambridge University Press), 129-142. http:// dx.doi.org/10.1017/CBO9780511626142.013

Daigle, H., and Screaton, E.J., 2015. Evolution of sediment permeability during burial and subduction. Geofluids, 15(1-2):84-105. http://dx.doi.org/10.1111/gfl.12090

DeMaster, D.J., 1981. The supply and accumulation of silica in the marine environment. Geochimica et Cosmochimica Acta, 45(10):1715-1732. http://dx.doi.org/ 10.1016/0016-7037(81)90006-5

Fisher, A.T., and Underwood, M.B., 1995. Calibration of an $\mathrm{X}$-ray diffraction method to determine relative mineral abundances in bulk powders using matrix singular value decomposition: a test from the Barbados accretionary complex. In Shipley, T.H., Ogawa, Y., Blum, P., et al., Proceedings of the Ocean Drilling Program, Initial Reports, 156: College Station, TX (Ocean Drilling Program), 29-37. http://dx.doi.org/10.2973/ odp.proc.ir.156.103.1995

Grasshoff, K., Ehrhardt, M., and Kemling, K. (Eds.), 1983. Methods of Seawater Analysis (2nd edition): Weinheim, Germany (Verlag Chemie).

Jaeger, J.M., Gulick, S.P.S., LeVay, L.J., Asahi, H., Bahlburg, H., Belanger, C.L., Berbel, G.B.B., Childress, L.B., Cowan, E.A., Drab, L., Forwick, M., Fukumura, A., Ge, S., Gupta, S.M., Kioka, A., Konno, S., März, C.E., Matsu- 
zaki, K.M., McClymont, E.L., Mix, A.C., Moy, C.M., Müller, J., Nakamura, A., Ojima, T., Ridgway, K.D., Rodrigues Ribeiro, F., Romero, O.E., Slagle, A.L., Stoner, J.S., St-Onge, G., Suto, I., Walczak, M.H., and Worthington, L.L., 2014. Expedition 341 summary. In Jaeger, J.M., Gulick, S.P.S., LeVay, L.J., and the Expedition 341 Scientists, Proceedings of the Integrated Ocean Drilling Program, 341: College Station, TX (Integrated Ocean Drilling Program). http://dx.doi.org/10.2204/ iodp.proc.341.101.2014

James, S.R., and Screaton, E.J., 2015. Data report: permeability of Expedition 344 sediments from the Costa Rica Seismogenesis Project. In Harris, R.N., Sakaguchi, A., Petronotis, K., and the Expedition 344 Scientists, Proceedings of the Integrated Ocean Drilling Program, 344: College Station, TX (Integrated Ocean Drilling Program). http://dx.doi.org/10.2204/iodp.proc.344.202.2015

Moore, D.M., and Reynolds, R.C., Jr., 1997. X-ray Diffraction and the Identification and Analysis of Clay Minerals (2nd edition): Oxford, United Kingdom (Oxford University Press).

Ryan, W.B.F., Carbotte, S.M., Coplan, J.O., O'Hara, S., Melkonian, A., Arko, R., Weissel, R.A., Ferrini, V., Goodwillie, A., Nitsche, F., Bonczkowski, J., and Zemsky, R., 2009. Global multi-resolution topography synthesis. Geochemistry, Geophysics, Geosystems, 10(3):Q03014. http://dx.doi.org/10.1029/2008GC002332

Saccone, L., Conley, D.J., and Sauer, D., 2006. Methodologies for amorphous silica analysis. Journal of Geochemical Exploration, 88(1-3):235-238. http://dx.doi.org/ 10.1016/j.gexplo.2005.08.045

Screaton, E.J., 2010. Recent advances in subseafloor hydrogeology: focus on basement-sediment interactions, subduction zones, and continental slopes. Hydrogeology Journal, 18(7):1547-1570. http://dx.doi.org/10.1007/ s10040-010-0636-7
Sharqawy, M.H., Lienhard, J.H., V, and Zubair, S.M., 2010. Thermophysical properties of seawater: a review of existing correlations and data. Desalination and Water Treatment, 16(1-3):354-380. http://dx.doi.org/ 10.5004/dwt.2010.1079

Spinelli, G.A., and Hutton, A., 2013. Data report: amorphous silica content of sediment from Sites C0011 and C0012 in the Shikoku Basin on the NanTroSEIZE transect. In Saito, S., Underwood, M.B., Kubo, Y., and the Expedition 322 Scientists, Proceedings of the Integrated Ocean Drilling Program, 322: Tokyo (Integrated Ocean Drilling Program Management International, Inc.). http://dx.doi.org/10.2204/ iodp.proc.322.204.2013

Spinelli, G.A., and Underwood, M.B., 2004. Character of sediments entering the Costa Rica subduction zone: implications for partitioning of water along the plate interface. Island Arc, 13(3):432-451. http://dx.doi.org/ 10.1111/j.1440-1738.2004.00436.x

Underwood, M.B., Basu, N., Steurer, J., and Udas, S., 2003. Data report: normalization factors for semiquantitative X-ray diffraction analysis, with application to DSDP Site 297, Shikoku Basin. In Mikada, H., Moore, G.F., Taira, A., Becker, K., Moore, J.C., and Klaus, A. (Eds.), Proceedings of the Ocean Drilling Program, Scientific Results, 190/ 196: College Station, TX (Ocean Drilling Program), 128. http://dx.doi.org/10.2973/

odp.proc.sr.190196.203.2003

Wang, H.F., 2000. Theory of Linear Poroelasticity with Applications to Geomechanics and Hydrogeology: Princeton, NJ (Princeton University Press).

Initial receipt: 27 July 2016

Acceptance: 25 January 2017

Publication: 14 April 2017

MS 341-202 
Figure F1. Locations of Expedition 341 Sites U1417 and U1418 (see the "Expedition 341 summary" chapter [Jaeger et al., 2014]). The figure was made using GeoMapApp and the default basemap (Ryan et al., 2009).

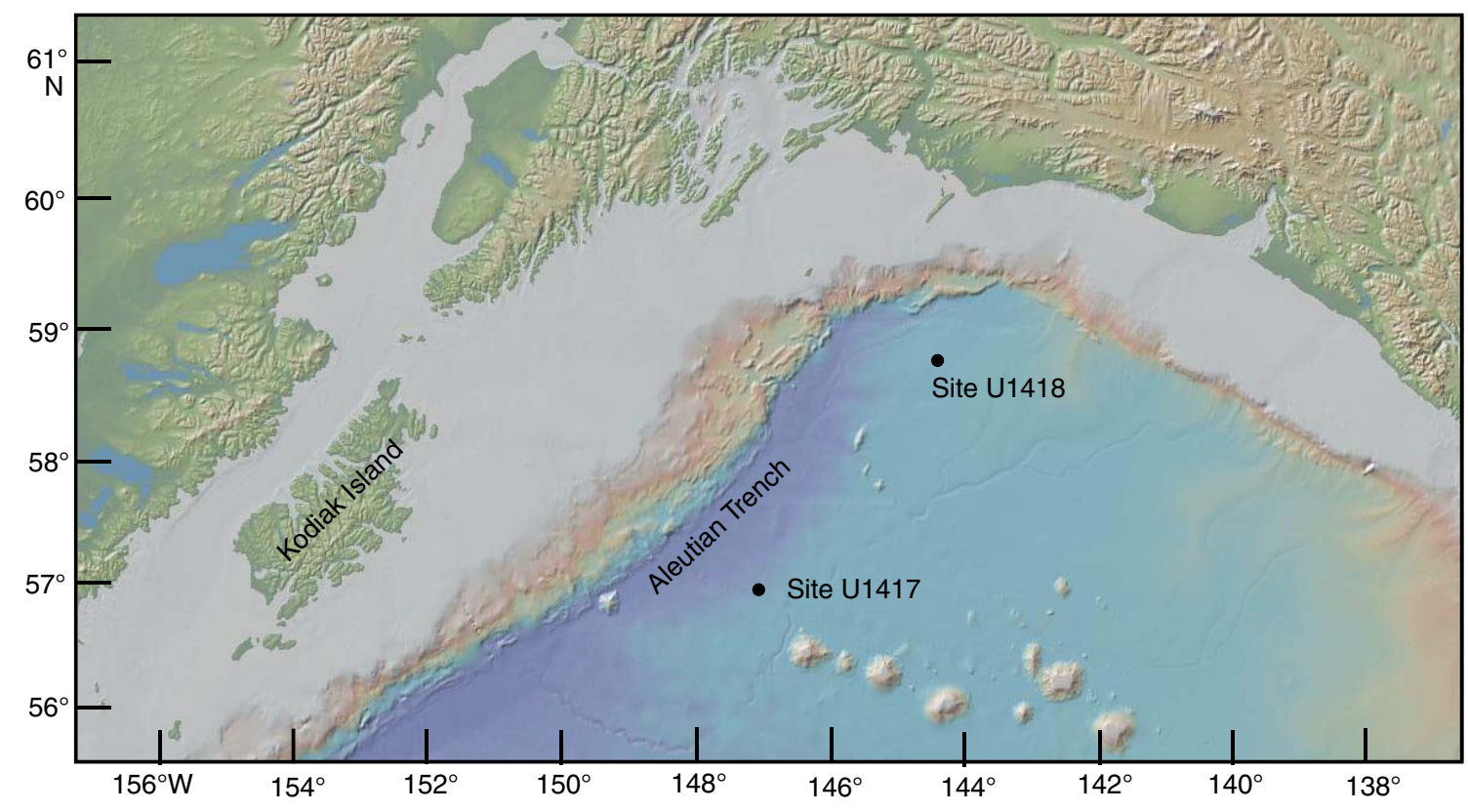


Figure F2. (A) Schematic of the permeability test system and (B) labeled photo of the permeability test system. The top, bottom, and cell pumps consist of $80 \mathrm{~mL}$ pistons that are moved upward or downward to infuse or extract water from the sample or cell. The interface chamber has a rubber diaphragm in the center to separate the seawater that is used as a permeant (bottom chamber) from the distilled water used in the pumps (top chamber). Deionized (DI) water is used in the cell pump and in the sample cell, which has a volume of $2300 \mathrm{~mL}$.

A

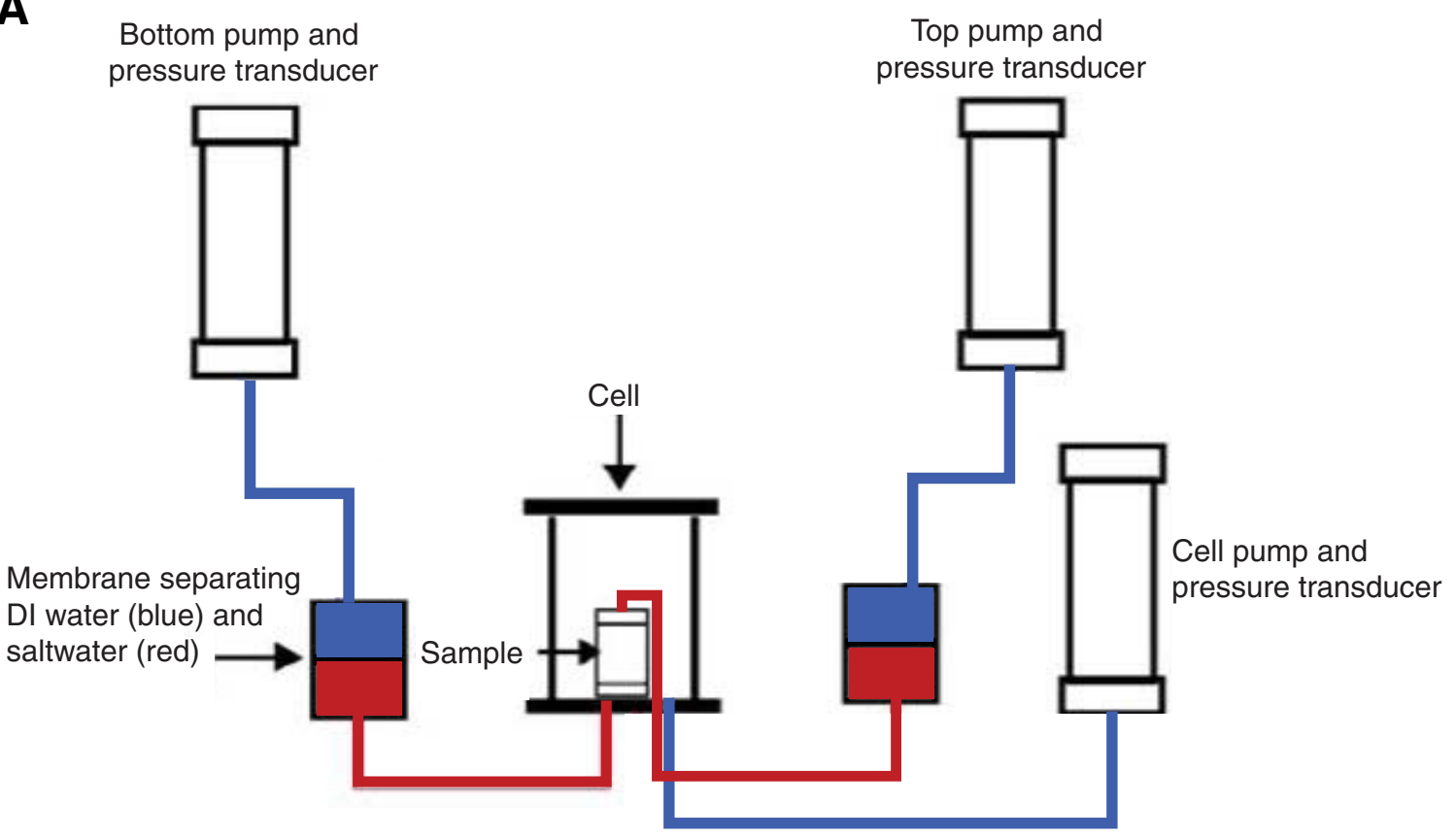

B

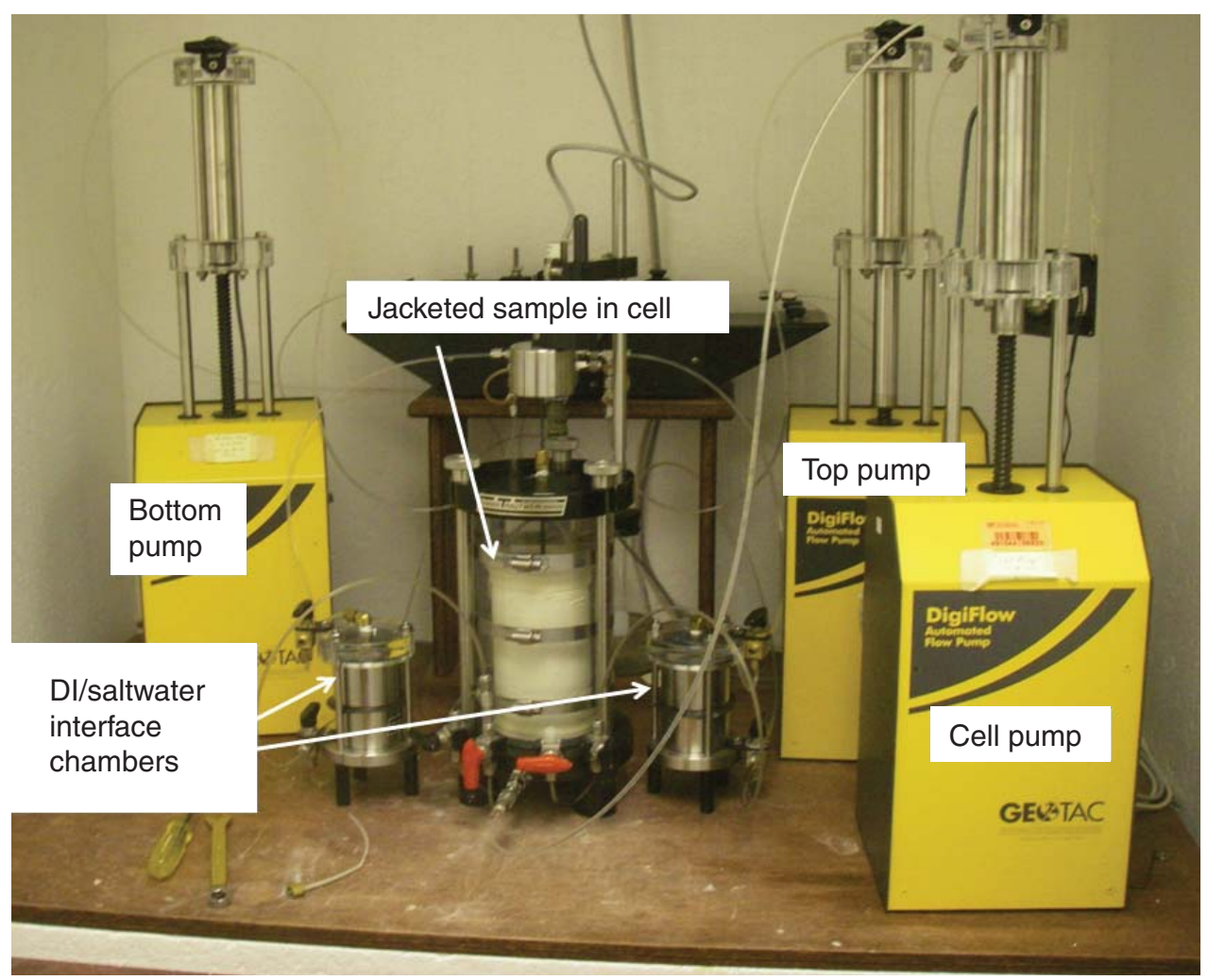


Figure F3. Example of X-ray diffraction analysis of sediment samples from Gulf of Alaska (Section 341-U1417E39R-7. A. Bulk sample diffraction pattern reflecting clay, quartz, and plagioclase content. Calcite is not present in this sample, but the location of the characteristic peak is indicated as identified in other samples of this study (Table T6). B. Result of the X-ray diffraction analysis of clay-size fraction after exposure to ethylene-glycol, reflecting the characteristic peaks of smectite, illite, and the shared peak of kaolinite/chlorite.
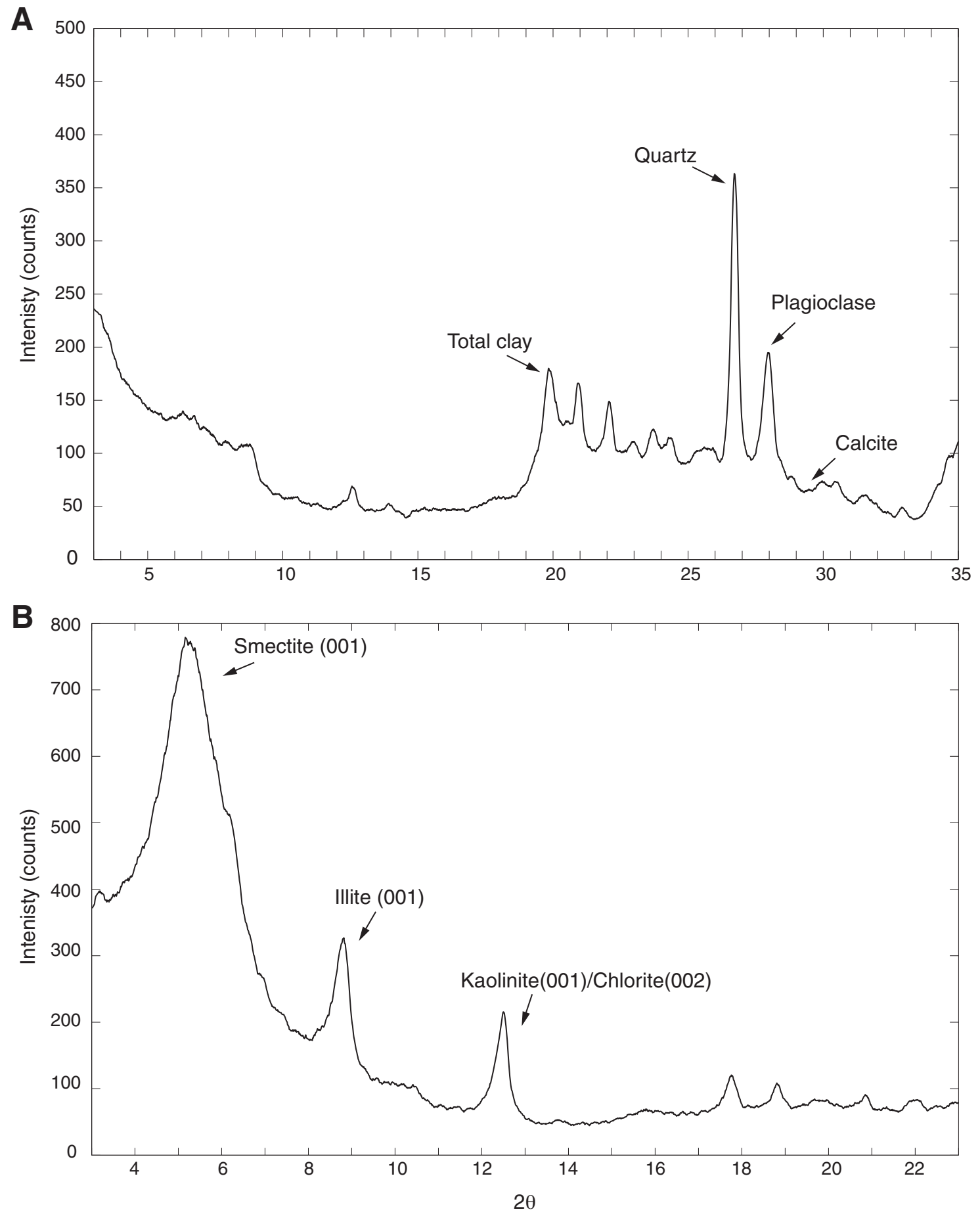
Figure F4. (A) Shipboard porosity (B) permeability at the highest effective stress for each sample, (C) biogenic silica content, (D) grain size analysis results, and (E) clay content in bulk sample, Site U1417.
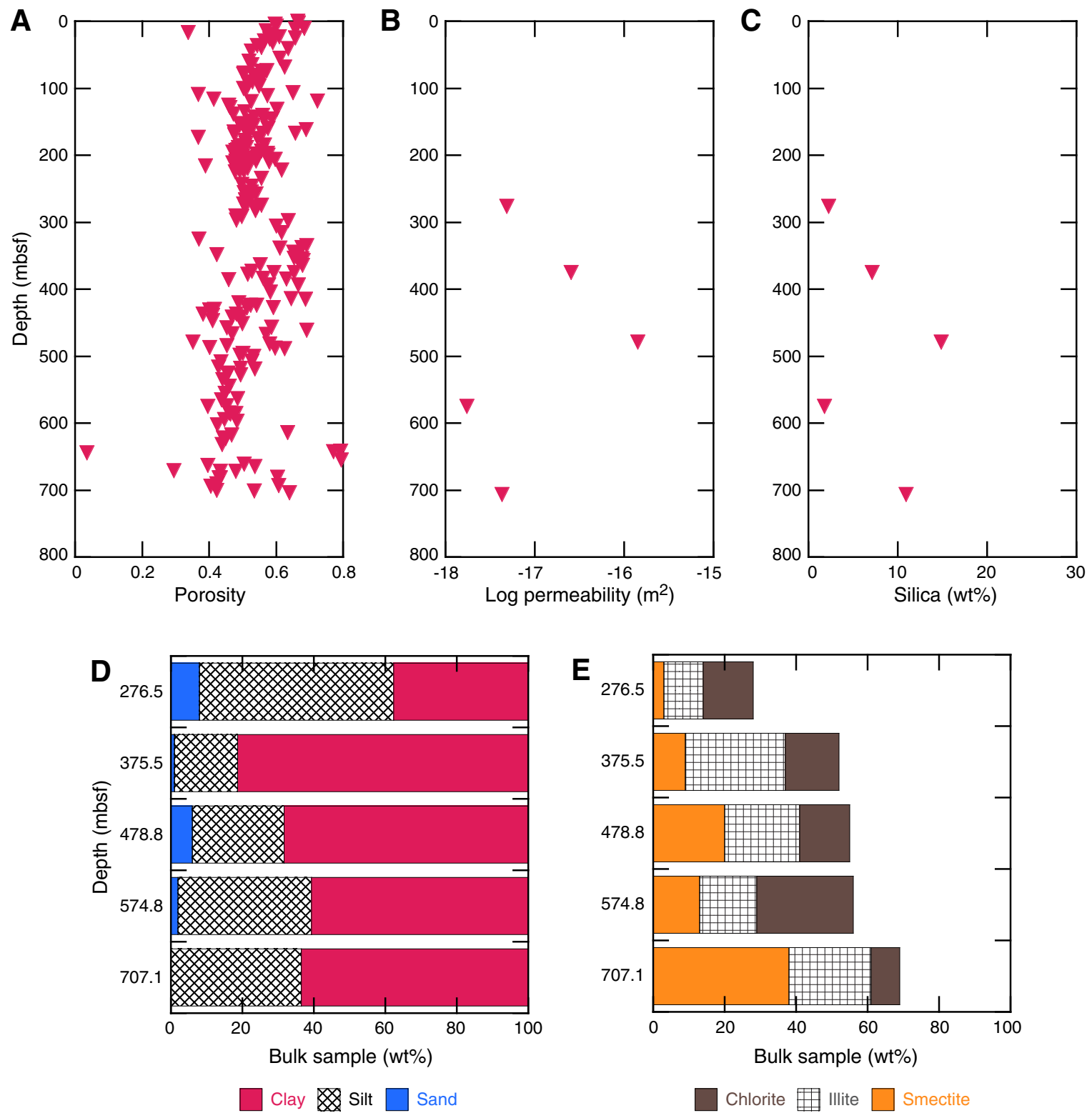

Chlorite 困 Illite $\square$ Smectite 
Figure F5. (A) Shipboard porosity (B) permeability at the highest effective stress for each sample, (C) biogenic silica content, (D) grain size analysis results, and (E) clay content in bulk sample, Site U1418.
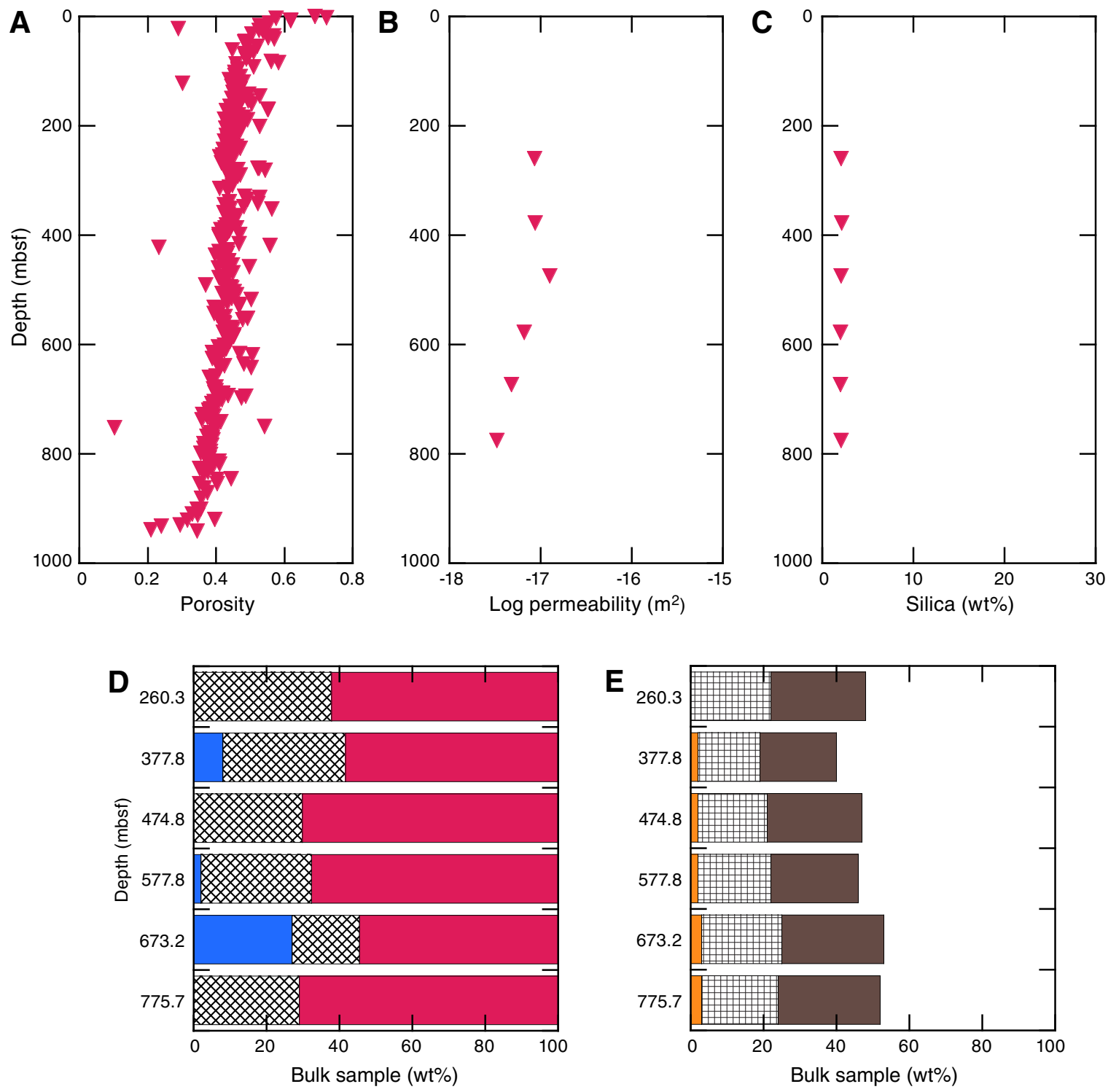

Clay Silt $\square$ Sand

Chlorite 曲 Illite $\square$ Smectite 
Table T1. Bulk powder mineral mixtures for calibration of normalization factors.

\begin{tabular}{|c|c|c|c|c|c|c|c|}
\hline \multirow[b]{2}{*}{ Mix } & \multicolumn{4}{|c|}{ Clay minerals (wt\%) } & \multicolumn{3}{|c|}{ Nonclay minerals (wt\%) } \\
\hline & Smectite & Illite & Chlorite & Total clay & Quartz & Plagioclase & Calcite \\
\hline 1 & 57 & 9 & 10 & 76 & 9 & 8 & 7 \\
\hline 2 & 12 & 26 & 33 & 71 & 11 & 11 & 7 \\
\hline 3 & 14 & 33 & 20 & 67 & 16 & 13 & 4 \\
\hline 4 & 33 & 6 & 24 & 63 & 11 & 10 & 16 \\
\hline 5 & 9 & 20 & 30 & 59 & 8 & 6 & 27 \\
\hline 6 & 38 & 7 & 8 & 53 & 27 & 10 & 10 \\
\hline 7 & 24 & 5 & 20 & 49 & 6 & 26 & 19 \\
\hline 8 & 19 & 9 & 13 & 41 & 30 & 5 & 24 \\
\hline 9 & 20 & 15 & 4 & 39 & 13 & 9 & 39 \\
\hline 10 & 10 & 13 & 13 & 36 & 19 & 15 & 30 \\
\hline 11 & 7 & 6 & 10 & 23 & 13 & 13 & 51 \\
\hline 12 & 6 & 8 & 6 & 20 & 6 & 5 & 69 \\
\hline 13 & 1 & 8 & 9 & 17 & 56 & 21 & 6 \\
\hline 14 & 8 & 1 & 6 & 15 & 46 & 38 & 2 \\
\hline 15 & 0 & 0 & 0 & 0 & 100 & 0 & 0 \\
\hline 16 & 0 & 0 & 0 & 0 & 0 & 100 & 0 \\
\hline 17 & 0 & 0 & 0 & 0 & 0 & 0 & 100 \\
\hline 18 & 50 & 50 & 0 & 100 & 0 & 0 & 0 \\
\hline
\end{tabular}

Table T2. Results from laboratory permeability tests and grain size analyses, Sites U1417 and U1418.

\begin{tabular}{|c|c|c|c|c|c|c|c|c|c|c|c|c|}
\hline $\begin{array}{l}\text { Core, } \\
\text { section }\end{array}$ & $\begin{array}{l}\text { Top depth } \\
\text { (mbsf) }\end{array}$ & $\begin{array}{l}\text { Shipboard } \\
\text { porosity }\end{array}$ & $\begin{array}{l}\text { Estimated in } \\
\text { situ effective } \\
\text { stress (MPa) }\end{array}$ & $\begin{array}{c}\text { Effective stress } \\
\text { during testing } \\
(\mathrm{MPa})\end{array}$ & $\begin{array}{l}\text { B-test } \\
\text { results }\end{array}$ & $\begin{array}{l}\text { Porosity } \\
\text { during } \\
\text { testing }\end{array}$ & $\begin{array}{l}\text { Number of } \\
\text { flow tests }\end{array}$ & $k\left(m^{2}\right)$ & $k \mathrm{SD}\left(\mathrm{m}^{2}\right)$ & $\begin{array}{c}\text { Sand } \\
(>63 \mu \mathrm{m}) \\
(w \mathrm{t} \%)\end{array}$ & Silt (wt\%) & $\begin{array}{c}\text { Clay } \\
(<4 \mu \mathrm{m}) \\
(\text { wt } \%)\end{array}$ \\
\hline \multicolumn{13}{|c|}{ 341-U1417D- } \\
\hline $43 X-3$ & 276.54 & 0.53 & 2.1 & 0.17 & 0.9 & 0.51 & 3 & $5.23 \mathrm{E}-18$ & $8.69 \mathrm{E}-20$ & 8 & 54.4 & 37.6 \\
\hline $43 X-3$ & 276.54 & 0.53 & 2.1 & 0.38 & 0.9 & 0.50 & 3 & $4.84 \mathrm{E}-18$ & $4.89 \mathrm{E}-20$ & 8 & 54.4 & 37.6 \\
\hline $54 \mathrm{X}-2$ & 375.48 & 0.59 & 2.8 & 0.38 & 0.96 & 0.55 & 3 & $2.58 \mathrm{E}-17$ & $4.85 \mathrm{E}-18$ & 1 & 17.7 & 81.3 \\
\hline \multicolumn{13}{|c|}{ 341-U1417E- } \\
\hline 15R-1 & 478.82 & 0.57 & 3.7 & 0.17 & 0.93 & 0.55 & 3 & $1.49 \mathrm{E}-16$ & $5.26 \mathrm{E}-18$ & 6 & 25.7 & 68.3 \\
\hline 15R-1 & 478.82 & 0.57 & 3.7 & 0.55 & 0.93 & 0.55 & 3 & $1.44 \mathrm{E}-16$ & $7.91 \mathrm{E}-18$ & 6 & 25.7 & 68.3 \\
\hline $25 \mathrm{R}-1$ & 574.75 & 0.44 & 4.6 & 0.17 & 0.91 & 0.37 & 4 & $1.90 \mathrm{E}-18$ & $6.76 \mathrm{E}-20$ & 2 & 37.4 & 60.6 \\
\hline $25 \mathrm{R}-1$ & 574.75 & 0.44 & 4.6 & 0.38 & 0.91 & 0.36 & 3 & $1.76 \mathrm{E}-18$ & $5.42 \mathrm{E}-20$ & 2 & 37.4 & 60.6 \\
\hline $39 R-7$ & 707.11 & 0.50 & 5.8 & 0.14 & 0.94 & 0.49 & 3 & $5.13 \mathrm{E}-18$ & $4.24 \mathrm{E}-19$ & 0 & 36.5 & 63.6 \\
\hline $39 R-7$ & 707.11 & 0.50 & 5.8 & 0.41 & 0.94 & 0.48 & 3 & $4.31 \mathrm{E}-18$ & 7.45E-20 & 0 & 36.5 & 63.6 \\
\hline \multicolumn{13}{|c|}{ 341-U1418D- } \\
\hline $33 X-3$ & 260.27 & 0.44 & 2.2 & 0.17 & NT & 0.37 & 3 & $8.61 \mathrm{E}-18$ & $2.90 \mathrm{E}-19$ & 0 & 37.8 & 62.2 \\
\hline $33 X-3$ & 260.27 & 0.44 & 2.2 & 0.38 & NT & 0.36 & 3 & $8.58 \mathrm{E}-18$ & 3.39E-19 & 0 & 37.8 & 62.2 \\
\hline \multicolumn{13}{|c|}{ 341-U1418F- } \\
\hline 14R-1 & 377.8 & 0.45 & 3.3 & 0.17 & 0.93 & 0.40 & 3 & $9.54 \mathrm{E}-18$ & $4.43 \mathrm{E}-19$ & 8 & 33.7 & 58.3 \\
\hline 14R-1 & 377.8 & 0.45 & 3.3 & 0.38 & 0.93 & 0.39 & 3 & 8.77E-18 & 2.77E-19 & 8 & 33.7 & 58.3 \\
\hline 24R-1 & 474.8 & 0.43 & 4.2 & 0.14 & 0.93 & 0.42 & 3 & $1.77 \mathrm{E}-17$ & 7.47E-19 & 0 & 29.9 & 70.1 \\
\hline 24R-1 & 474.8 & 0.43 & 4.2 & 0.41 & 0.93 & 0.39 & 3 & $1.26 \mathrm{E}-17$ & $5.27 \mathrm{E}-19$ & 0 & 29.9 & 70.1 \\
\hline $34 R-5$ & 577.8 & 0.42 & 5.1 & 0.17 & 0.97 & 0.38 & 3 & $7.22 \mathrm{E}-18$ & $1.90 \mathrm{E}-19$ & 2 & 30.4 & 67.6 \\
\hline $34 \mathrm{R}-5$ & 577.8 & 0.42 & 5.1 & 0.38 & 0.97 & 0.37 & 3 & $6.63 \mathrm{E}-18$ & $1.81 \mathrm{E}-19$ & 2 & 30.4 & 67.6 \\
\hline $44 R-4$ & 673.16 & 0.40 & 6.0 & 0.24 & 0.90 & 0.37 & 4 & $6.20 \mathrm{E}-18$ & $2.08 \mathrm{E}-18$ & 27 & 18.5 & 54.5 \\
\hline 44R-4 & 673.16 & 0.40 & 6.0 & 0.52 & 0.90 & 0.34 & 4 & $4.78 \mathrm{E}-18$ & $1.84 \mathrm{E}-18$ & 27 & 18.5 & 54.5 \\
\hline $55 \mathrm{R}-2$ & 775.69 & 0.39 & 7.0 & 0.10 & 0.90 & 0.38 & 3 & $5.19 \mathrm{E}-18$ & $5.65 \mathrm{E}-20$ & 0 & 29 & 71 \\
\hline $55 \mathrm{R}-2$ & 775.69 & 0.39 & 7.0 & 0.52 & 0.90 & 0.34 & 4 & $3.31 \mathrm{E}-18$ & $6.80 \mathrm{E}-19$ & 0 & 29 & 71 \\
\hline
\end{tabular}

Estimated in situ effective stress was computed using bulk density values from the sites and assuming hydrostatic pore pressures. The testing effective stress was computed as the confining pressure minus the average of the pressures measured at the top and bottom pump. $k=h y d r a u l i c$ conductivity, SD = standard deviation. NT = not tested. 
Table T3. Results from amorphous silica analyses, Sites U1417 and U1418.

\begin{tabular}{cc}
\hline $\begin{array}{c}\text { Core, } \\
\text { section }\end{array}$ & $\begin{array}{c}\text { Amorphous } \\
\text { silica (wt\%) }\end{array}$ \\
\hline 341-U1417D- & \\
43X-3 & 2.25 \\
$54 \mathrm{X}-2$ & 7.16 \\
341-U1417E- & \\
15R-1 & 14.92 \\
25R-1 & 1.83 \\
39R-7 & 10.94 \\
341-U1418D- & \\
33X-3 & 2.11 \\
341-U1418F- & \\
14R-1 & 2.12 \\
24R-1 & 2.10 \\
34R-5 & 2.02 \\
44R-4 & 1.98 \\
55R-2 & 2.08 \\
\hline
\end{tabular}

Table T4. X-ray diffraction results for bulk mineral standard mixtures.

\begin{tabular}{|c|c|c|c|c|c|c|c|c|c|c|c|c|}
\hline \multirow[b]{2}{*}{ Mix } & \multicolumn{4}{|c|}{ Basal peak area (counts) } & \multicolumn{4}{|c|}{ Calculated abundance (wt\%) } & \multicolumn{4}{|c|}{ Error (wt\%; calculated - measured) } \\
\hline & $\begin{array}{c}\text { Total clay } \\
(4.49 \AA)\end{array}$ & $\begin{array}{l}\text { Quartz } \\
(3.34 \AA)\end{array}$ & $\begin{array}{c}\text { Plagioclase } \\
(3.21-3.18 \AA)\end{array}$ & $\begin{array}{l}\text { Calcite } \\
(3.04 \AA)\end{array}$ & $\begin{array}{l}\text { Total clay } \\
(4.49 \AA)\end{array}$ & $\begin{array}{l}\text { Quartz } \\
(3.34 \AA)\end{array}$ & $\begin{array}{c}\text { Plagioclase } \\
(3.21-3.18 \AA)\end{array}$ & $\begin{array}{l}\text { Calcite } \\
(3.04 \AA)\end{array}$ & $\begin{array}{c}\text { Total clay } \\
(4.49 \AA)\end{array}$ & $\begin{array}{l}\text { Quartz } \\
(3.34 \AA)\end{array}$ & $\begin{array}{c}\text { Plagioclase } \\
(3.21-3.18 \AA)\end{array}$ & $\begin{array}{c}\text { Calcite } \\
(3.04 \AA)\end{array}$ \\
\hline 1 & 364 & 360 & 234 & 222 & 77 & 9 & 8 & 6 & 0.8 & 0.4 & 0.0 & -1.1 \\
\hline 2 & 251 & 393 & 289 & 158 & 69 & 14 & 12 & 5 & -2.1 & 2.6 & 1.2 & -1.7 \\
\hline 3 & 222 & 571 & 307 & 130 & 63 & 21 & 13 & 4 & -4.2 & 4.6 & 0.1 & -0.5 \\
\hline 4 & 258 & 336 & 248 & 337 & 63 & 10 & 10 & 18 & -0.4 & -0.7 & -0.5 & 1.6 \\
\hline 5 & 177 & 276 & 153 & 456 & 51 & 10 & 7 & 32 & -8.2 & 2.1 & 1.1 & 4.9 \\
\hline 6 & 219 & 702 & 272 & 236 & 56 & 23 & 10 & 11 & 2.7 & -4.3 & 0.4 & 1.1 \\
\hline 7 & 169 & 200 & 496 & 386 & 47 & 7 & 20 & 26 & -1.9 & 1.3 & -6.3 & 6.9 \\
\hline 8 & 136 & 745 & 119 & 431 & 39 & 26 & 5 & 29 & -1.3 & -4.5 & 0.1 & 5.7 \\
\hline 9 & 93 & 355 & 166 & 595 & 32 & 14 & 8 & 46 & -7.5 & 0.8 & -0.9 & 7.6 \\
\hline 10 & 92 & 490 & 302 & 543 & 30 & 18 & 13 & 40 & -6.4 & -1.2 & -2.3 & 9.9 \\
\hline 11 & 51 & 291 & 243 & 794 & 21 & 11 & 10 & 58 & -2.4 & -1.9 & -2.6 & 7.0 \\
\hline 12 & 50 & 127 & 177 & 833 & 22 & 6 & 8 & 64 & 1.8 & 0.2 & 3.5 & -5.5 \\
\hline 13 & 45 & 1508 & 505 & 126 & 16 & 56 & 21 & 7 & -1.1 & 0.4 & -0.1 & 0.7 \\
\hline 14 & 45 & 1352 & 1203 & 60 & 14 & 43 & 43 & 0 & -0.7 & -2.5 & 4.9 & -1.7 \\
\hline 15 & 0 & 3059 & 0 & 0 & 4 & 96 & 0 & 0 & 3.8 & -3.8 & 0.0 & 0.0 \\
\hline 16 & 0 & 0 & 2583 & 0 & 3 & 1 & 97 & 0 & 2.6 & 0.7 & -3.2 & 0.0 \\
\hline 17 & 0 & 0 & 0 & 1050 & 11 & 3 & 2 & 84 & 11.4 & 2.5 & 2.2 & -16.1 \\
\hline 18 & 406 & 0 & 0 & 0 & 99 & 0 & 1 & 0 & -0.5 & 0.0 & 0.5 & 0.0 \\
\hline
\end{tabular}

Table T5. Normalization factors for X-ray diffraction of bulk mineral standard mixtures.

\begin{tabular}{lcccc}
\hline $\begin{array}{c}\text { Influencing } \\
\text { mineral }\end{array}$ & Total clay & Quartz & Plagioclase & Calcite \\
\hline Total clay & $2.45 \mathrm{E}-01$ & $1.34 \mathrm{E}-03$ & $1.01 \mathrm{E}-03$ & $1.07 \mathrm{E}-02$ \\
Quartz & -0.00401 & 0.033768 & 0.000262 & 0.002388 \\
Plagioclase & 0.001305 & -0.00051 & 0.038046 & 0.002071 \\
Calcite & -0.02622 & -0.00142 & -0.00115 & 0.078711 \\
\hline
\end{tabular}


Table T6. X-ray diffraction results for bulk sediment samples, Sites U1417 and U1418.

\begin{tabular}{|c|c|c|c|c|c|c|c|c|}
\hline \multirow[b]{2}{*}{$\begin{array}{l}\text { Core, } \\
\text { section }\end{array}$} & \multicolumn{4}{|c|}{ Basal peak area (counts) } & \multicolumn{4}{|c|}{ Calculated abundance (wt\%) } \\
\hline & $\begin{array}{c}\text { Total clay } \\
(4.49 \AA)\end{array}$ & $\begin{array}{l}\text { Quartz } \\
(3.34 \AA)\end{array}$ & $\begin{array}{c}\text { Plagioclase } \\
(3.21-3.18 \AA)\end{array}$ & $\begin{array}{l}\text { Calcite } \\
(3.04 \AA)\end{array}$ & $\begin{array}{l}\text { Total clay } \\
(4.49 \AA)\end{array}$ & $\begin{array}{l}\text { Quartz } \\
(3.34 \AA)\end{array}$ & $\begin{array}{c}\text { Plagioclase } \\
(3.21-3.18 \AA)\end{array}$ & $\begin{array}{l}\text { Calcite } \\
(3.04 \AA)\end{array}$ \\
\hline \multicolumn{9}{|c|}{ 341-U1417D- } \\
\hline $43 X-3$ & 59.8 & 442.5 & 527.4 & 104.5 & 29 & 26 & 35 & 9 \\
\hline $54 X-2$ & 123.7 & 277.0 & 419.8 & 0.1 & 56 & 16 & 28 & 0 \\
\hline \multicolumn{9}{|c|}{ 341-U1417E- } \\
\hline 15R-1 & 206.3 & 298.9 & 505.2 & 0.1 & 64 & 12 & 24 & 0 \\
\hline 25R-1 & 147.3 & 387.6 & 395.2 & 0.1 & 57 & 20 & 23 & 0 \\
\hline $39 R-7$ & 272.0 & 233.9 & 338.0 & 0.1 & 77 & 8 & 15 & 0 \\
\hline \multicolumn{9}{|c|}{ 341-U1418D- } \\
\hline $33 X-3$ & 103.4 & 356.6 & 409.0 & 7.7 & 49 & 22 & 29 & 0 \\
\hline \multicolumn{9}{|c|}{ 341-U1418F- } \\
\hline 14R-1 & 106.2 & 458.4 & 558.6 & 88.7 & 41 & 23 & 31 & 4 \\
\hline 24R-1 & 123.8 & 389.2 & 497.4 & 89.4 & 48 & 19 & 28 & 4 \\
\hline $34 R-5$ & 108.6 & 387.9 & 433.6 & 90.4 & 47 & 21 & 27 & 5 \\
\hline 44R-4 & 153.2 & 442.0 & 471.6 & 14.4 & 54 & 20 & 25 & 0 \\
\hline $55 \mathrm{R}-2$ & 153.2 & 423.5 & 495.8 & 87.5 & 53 & 19 & 26 & 2 \\
\hline
\end{tabular}

Table T7. X-ray diffraction results for clay-size fraction $(<2 \mu \mathrm{m})$ in samples, Sites U1417 and U1418.

\begin{tabular}{|c|c|c|c|c|c|c|c|c|c|c|c|c|c|c|}
\hline \multirow[b]{2}{*}{$\begin{array}{c}\text { Core, } \\
\text { section }\end{array}$} & \multicolumn{3}{|c|}{ Basal peak area (counts) } & \multicolumn{4}{|c|}{ Peak area correction } & \multicolumn{3}{|c|}{$\begin{array}{l}\text { Relative clay size fraction content } \\
\qquad(w t \%)\end{array}$} & \multirow{2}{*}{$\begin{array}{c}\text { Bulk } \\
\text { sample } \\
\text { clay } \\
\text { mineral } \\
\text { content } \\
(\%)\end{array}$} & \multicolumn{3}{|c|}{$\begin{array}{l}\text { Bulk sample relative clay } \\
\text { mineral content (wt\%) }\end{array}$} \\
\hline & $\begin{array}{c}\text { Smectite } \\
(17 \AA)\end{array}$ & $\begin{array}{l}\text { Illite } \\
(10 \AA)\end{array}$ & $\begin{array}{c}\text { Kaolinite/ } \\
\text { Chlorite* } \\
(7 \AA)\end{array}$ & $\begin{array}{c}1 \times \\
\text { smectite }\end{array}$ & $4 \times$ illite & $\begin{array}{c}2 \times \\
\text { kaolinite/ } \\
\text { chlorite }^{*}\end{array}$ & Total & $\begin{array}{l}\text { Smectite } \\
(17 \AA)\end{array}$ & $\begin{array}{l}\text { Illite } \\
(10 \AA)\end{array}$ & $\begin{array}{c}\text { Kaolinite/ } \\
\text { Chlorite } \\
(7 \AA)\end{array}$ & & Smectite & Illite & Chlorite \\
\hline \multicolumn{15}{|c|}{ 341-U1417D- } \\
\hline $43 X-3$ & 451.3 & 383.4 & 946.3 & 451.3 & 1533.6 & 1892.6 & 3877.5 & 12 & 40 & 49 & 29 & 3 & 11 & 14 \\
\hline $54 X-2$ & 417.1 & 338.0 & 377.4 & 417.1 & 1352.0 & 754.8 & 2523.9 & 17 & 54 & 30 & 52 & 9 & 28 & 15 \\
\hline \multicolumn{15}{|c|}{ 341-U1417E- } \\
\hline 15R-1 & 792.5 & 202.8 & 263.6 & 792.5 & 811.2 & 527.2 & 2130.9 & 37 & 38 & 25 & 55 & 20 & 21 & 14 \\
\hline $25 \mathrm{R}-1$ & 871.4 & 259.9 & 899.6 & 871.4 & 1039.6 & 1799.2 & 3710.2 & 23 & 28 & 48 & 56 & 13 & 16 & 27 \\
\hline 39R-7 & 1184.6 & 175.1 & 117.4 & 1184.6 & 700.4 & 234.8 & 2119.8 & 56 & 33 & 11 & 69 & 38 & 23 & 8 \\
\hline \multicolumn{15}{|c|}{ 341-U1418D- } \\
\hline $33 X-3$ & 0.0 & 369.4 & 868.9 & 0.0 & 1477.6 & 1737.8 & 3215.4 & 0 & 46 & 54 & 48 & 0 & 22 & 26 \\
\hline \multicolumn{15}{|c|}{ 341-U1418F- } \\
\hline 14R-1 & 227.1 & 436.7 & 1051.3 & 227.1 & 1746.8 & 2102.6 & 4076.5 & 6 & 43 & 52 & 41 & 2 & 17 & 21 \\
\hline $24 \mathrm{R}-1$ & 124.2 & 273.3 & 762.2 & 124.2 & 1093.2 & 1524.4 & 2741.8 & 5 & 40 & 56 & 47 & 2 & 19 & 26 \\
\hline $34 \mathrm{R}-5$ & 106.6 & 291.1 & 677.1 & 106.6 & 1164.4 & 1354.2 & 2625.2 & 4 & 44 & 52 & 46 & 2 & 20 & 24 \\
\hline $44 \mathrm{R}-4$ & 234.9 & 382.9 & 973.1 & 234.9 & 1531.6 & 1946.2 & 3712.7 & 6 & 41 & 52 & 53 & 3 & 22 & 28 \\
\hline $55 \mathrm{R}-2$ & 208.3 & 350.6 & 961.7 & 208.3 & 1402.4 & 1923.4 & 3534.1 & 6 & 40 & 54 & 52 & 3 & 21 & 28 \\
\hline
\end{tabular}

* $=$ either kaolinite or chlorite. 